Check for updates

Cite this: RSC Adv., 2019, 9, 4488

Received 16th November 2018

Accepted 21st January 2019

DOI: $10.1039 / c 8 r a 09451 a$

rsc.li/rsc-advances

\section{Biogas production and metal passivation analysis during anaerobic digestion of pig manure: effects of a magnetic $\mathrm{Fe}_{3} \mathrm{O}_{4} /$ FA composite supplement}

\author{
Chunruan Liu, Qiao Tong, Yucheng Li, (D)* Ning Wang, Bingxiang Liu \\ and Xuesheng Zhang*
}

\begin{abstract}
Anaerobic digestion has been widely used to produce biogas renewable energy and stabilize fecal manure. In this work, magnetic fly ash composites $\left(\mathrm{Fe}_{3} \mathrm{O}_{4} / \mathrm{FA}\right)$ were synthesized and mixed with pig manure in different ratios to study their effects on biogas production and metal passivation during anaerobic digestion. The results showed that the use of $0.5 \% \mathrm{Fe}_{3} \mathrm{O}_{4} / \mathrm{FA}$ presented the most positive impact on biogas production compared to anaerobic digestion without $\mathrm{Fe}_{3} \mathrm{O}_{4} / \mathrm{FA}$, i.e., the total biogas and methane content increased by $13.81 \%$ and $35.13 \%$, respectively. Variations in the concentration and speciation of heavy metals (i.e., $\mathrm{Cu}$ and $\mathrm{Zn}$ ) with and without $\mathrm{Fe}_{3} \mathrm{O}_{4} / \mathrm{FA}$ during anaerobic digestion were also analyzed. The concentrations of $\mathrm{Cu}$ and $\mathrm{Zn}$ increased after anaerobic digestion, showing a significant "relative concentration effect". Additionally, sequential fractionation suggested that $\mathrm{Cu}$ was mainly present in organic matter, whereas $\mathrm{Zn}$ was mainly distributed in the oxidation states of iron and manganese. The addition of $\mathrm{Fe}_{3} \mathrm{O}_{4} / \mathrm{FA}$ enhanced the passivation of $\mathrm{Cu}$ and $\mathrm{Zn}$ in the solid digested residues, i.e., the residual states of $\mathrm{Cu}$ and $\mathrm{Zn}$ increased by $10.73 \%$ to $45.78 \%$ and $33.49 \%$ to $42.14 \%$ compared to the control, respectively. Moreover, better performance was found for the treatment with 2.5\% $\quad \mathrm{Fe}_{3} \mathrm{O}_{4} / \mathrm{FA}$. X-ray diffraction (XRD) and scanning electron microscopy-energy dispersive $\mathrm{X}$-ray spectroscopy (SEM-EDX) analysis demonstrated that $\mathrm{Fe}_{3} \mathrm{O}_{4} /$ FA deactivated heavy metals mainly via physical adsorption during anaerobic digestion, which can convert them into stable mineral precipitates and thus decrease the solubility and mobility of these metals.
\end{abstract}

\section{Introduction}

In recent years, rapid economic development and improvement of human living standards have stimulated imperative demands for meat and milk, promoting the rapid expansion of the livestock industry. The amount of fecal manure in China reached approximately 38 billion tons in 2016. ${ }^{1}$ In addition, fecal manure contains numerous heavy metals, such as copper $(\mathrm{Cu})$ and zinc $(\mathrm{Zn})$, due to the addition of heavy metals to feed..$^{2-4}$ Pig manure can provide indispensable nutrient elements for plants, such as nitrogen and phosphorus; it can be used as an effective alternative to synthetic $\mathrm{N}$ and $\mathrm{P}$ fertilizers. ${ }^{5}$ However, it can also cause serious heavy metal pollution of soil when metal-containing fecal manure is continuously introduced to farmland. ${ }^{6,7}$ These heavy metals can accumulate and enter the soil-water-plant system; this may cause risks to human health via the food chain.

The heavy metal pollution caused by fecal manure has been investigated by researchers worldwide. ${ }^{\mathbf{8}, \mathbf{9}}$ Anaerobic digestion was found to be an effective way to control fecal pollution from large-scale livestock and poultry farms. ${ }^{\mathbf{1 0 - 1 2}}$ Different types of digestion catalysts (e.g., fly ash (FA), phosphate, zeolite and

School of Resources and Environmental Engineering, Anhui University, Hefei 230601, Anhui, China. E-mail: li-yucheng@163.com; zhangqing8725@163.com biochar) have been added to the anaerobic digestion system to improve biogas production and decrease the bioavailability of heavy metals in fecal manure. ${ }^{\mathbf{1 3 - 1 5}}$ Nanoparticles were also found to have great potential to accelerate the hydrolysis of anaerobic digestion, improve methane yield and stabilize the sludge. ${ }^{16-18}$ Previous studies reported that FA can decrease the contents of soluble and exchangeable heavy metals via adsorption or changing the $\mathrm{pH} \cdot{ }^{\mathbf{1 9 , 2 0}} \mathrm{Lu}$ et al. recently found that the combined use of straw, sepiolite, coal fly ash $(2.5 \%)$ and phosphate rock $(5.0 \%)$ can result in efficient passivation of $\mathrm{Cu}$ during aerobic composting treatment. ${ }^{21}$ Additionally, enhanced effects of fly ash on the biodegradability and methane production of secondary paper and pulp sludge were reported. ${ }^{22}$

It has been proved that $\mathrm{Fe}_{3} \mathrm{O}_{4}$ nanoparticles can effectively promote methanogenesis through facilitating direct interspecies electron transfer in syntrophic methane production. ${ }^{23}$ Suanon et al. recently studied the influence of nanoscale zerovalent iron (ZVI) and $\mathrm{Fe}_{3} \mathrm{O}_{4}$ on the behavior and fate of heavy metals during anaerobic digestion of sludge. ${ }^{24}$ Compared with anaerobic digestion without iron nanoparticles, the use of $0.5 \%$ iron nanoparticles led to increased biogas production and improved metal stabilization in the digestate. However, to date, information regarding the possible effects of magnetic $\mathrm{Fe}_{3} \mathrm{O}_{4}$ / FA composites on biogas production and metal passivation 
during anaerobic digestion of pig manure has remained insufficient.

The current work was designed and performed to evaluate the potential effects of $\mathrm{Fe}_{3} \mathrm{O}_{4} / \mathrm{FA}$ composites on methane production and stabilization of heavy metals (e.g., $\mathrm{Cu}$ and $\mathrm{Zn}$ ) during anaerobic digestion. Pig manure was spiked with $\mathrm{Fe}_{3} \mathrm{O}_{4} /$ FA composites and treated via an anaerobic digestion process. The basic physiochemical properties during anaerobic digestion were determined, including $\mathrm{pH}$, total solids (TS), volatile solids (VS), ammonium nitrogen $\left(\mathrm{NH}_{4}{ }^{+}-\mathrm{N}\right)$, elemental analysis ( $\mathrm{C}$ and $\mathrm{N}$ ), chemical oxygen demand (COD) and methane $\left(\mathrm{CH}_{4}\right)$ production. The stabilization of heavy metals was assessed based on their distribution in the final product compared to the original pig manure. The modified Gompertz model was used to fit the experimental results and predict the methane yield of each manure sample in anaerobic digestion. Additionally, the mineral composition, morphology and element content of the heavy metal residual fractions before and after anaerobic digestion were characterized to understand the possible mechanism of heavy metal passivation.

\section{Experimental section}

\section{Materials and methods}

Naturally air-dried pig manure was supplied by a pig farm in Lujiang County (Hefei, Anhui, China). The manure was stored at $4{ }^{\circ} \mathrm{C}$ for further use. The inoculum was collected from the anaerobic digestion tank of a sewage treatment plant of a food company in Hefei City (Anhui, China) and domesticated at medium temperature $(35 \pm 1)^{\circ} \mathrm{C}$ for about 15 days. Portions of the manure and inoculum were dried in an oven at $105{ }^{\circ} \mathrm{C}$ to constant weight and then ground and screened with 200 meshes for physicochemical characterization (Table 1). FA was collected from the Hefei thermal power plant. Ferric sulfate $(>96 \%)$, ferrous sulfate $(>99 \%)$, and sodium hydroxide $(>96 \%)$ were purchased from Sinopharm Chemical Reagents Co. Ltd. (Shanghai, China).

\section{Preparation of $\mathrm{Fe}_{3} \mathrm{O}_{4} / \mathrm{FA}$ composites}

The magnetic $\mathrm{Fe}_{3} \mathrm{O}_{4} / \mathrm{FA}$ composites were synthesized by liquid phase co-precipitation. Briefly, $9.25 \mathrm{~g} \mathrm{Fe}_{2}\left(\mathrm{SO}_{4}\right)_{3} \cdot n \mathrm{H}_{2} \mathrm{O}(n=6$ to 9) and $18.29 \mathrm{~g} \mathrm{FeSO} \cdot 7 \mathrm{H}_{2} \mathrm{O}$ were firstly dissolved in $650 \mathrm{~mL}$ and $75 \mathrm{~mL}$ deionized water, respectively. The above two solutions were combined and vigorously stirred at $25{ }^{\circ} \mathrm{C}$ to $30^{\circ} \mathrm{C}$. FA $(25 \mathrm{~g}$, $60 \mathrm{mesh})$ was suspended in distilled water $(250 \mathrm{~mL})$ and then

Table 1 Physicochemical characterization of the materials ${ }^{a}$

\begin{tabular}{lrrl}
\hline Characteristic & \multicolumn{1}{c}{ Pig manure } & \multicolumn{1}{l}{ Inoculum } & FA \\
\hline TS $(\%)$ & $81.75 \pm 1.03$ & $8.31 \pm 0.07$ & nd \\
VS $(\%)$ & $70.98 \pm 0.34$ & $7.76 \pm 0.07$ & nd \\
pH & $8.06 \pm 0.10$ & $7.15 \pm 1.32$ & $8.5 \pm 1.21$ \\
TC $(\%)$ & $34.09 \pm 3.14$ & $30.27 \pm 1.49$ & nd \\
TN (\%) & $2.31 \pm 0.21$ & $5.06 \pm 1.24$ & nd \\
C/N & $14.76 \pm 2.72$ & $5.98 \pm 2.76$ & nd \\
Cu $\left(\mathrm{mg} \mathrm{kg}^{-1}\right)$ & $273.12 \pm 8.64$ & $72.10 \pm 12.99$ & $79.16 \pm 3.20$ \\
Zn $\left(\mathrm{mg} \mathrm{kg}^{-1}\right)$ & $1990.86 \pm 14.33$ & $492.00 \pm 13.89$ & $150.32 \pm 3.00$
\end{tabular}

${ }^{a}$ nd: non-detectable. mixed with the above solution. The suspension was slowly stirred at room temperature for $30 \mathrm{~min}$. Subsequently, $10 \mathrm{M}$ $\mathrm{NaOH}$ solution was added dropwise to the $\mathrm{FA} / \mathrm{Fe}^{2+} / \mathrm{Fe}^{3+}$ suspension until the solution $\mathrm{pH}$ reached 10.0 to 11.0. After mixing for $60 \mathrm{~min}$, the suspension was aged at room temperature for $24 \mathrm{~h}$, filtered, and then repeatedly washed with distilled water followed by ethanol. The $\mathrm{Fe}_{3} \mathrm{O}_{4} / \mathrm{FA}$ composites were vacuum-filtered and dried under vacuum at $60{ }^{\circ} \mathrm{C}$ for $10 \mathrm{~h}$.

\section{Anaerobic digestion and experimental design}

Anaerobic digestion experiments were carried out in the laboratory. Four sets of batch experiments were set up: a blank control (CK) and treatments with $\mathrm{Fe}_{3} \mathrm{O}_{4} / \mathrm{FA}$ at different doses (i.e., $0.5 \%, 1.0 \%$ and $2.5 \%$ on the basis of $\mathrm{TS}_{\text {added }}$ ). The dry matter of pig manure was set to $150 \mathrm{~g}$, and a glass bottle with a working volume of $2000 \mathrm{~mL}$ was used as the reactor; the inoculation of domesticated sludge was $30 \%$ ( $/ \mathrm{v}_{\text {working volume) }}$. The water addition was adjusted so that the TS load in the digestive system was $8 \%$. All mixtures were homogenous and flushed with nitrogen gas for $5 \mathrm{~min}$ to ensure anaerobic conditions before starting the experiments, and the mixtures were placed in a constant temperature incubator $(35.0 \pm 1.0)^{\circ} \mathrm{C}$. The biogas volume was recorded daily by reading the water displacement inside the calibrate glass cylinder in the reactor.

Each reactor was manually mixed three times daily (6:00 am, 14:00 pm and 22:00 pm) to avoid stratification during anaerobic digestion. The $\mathrm{pH}, \mathrm{NH}_{4}{ }^{+}-\mathrm{N}, \mathrm{COD}$ and volatile fatty acids (VFAs) of the liquid samples were measured every two or three days. On the completion of digestion (35th $\mathrm{d}$ ), the samples were collected, followed by solid-liquid separation. The separated liquid was stored in the refrigerator at $4{ }^{\circ} \mathrm{C}$. The solid residues were freeze-dried (ALPHA 1-2 LD plus, Christ, Germany), ground and sieved (100 mesh) for measurements of metal forms.

\section{Analytical methods}

A modified Gompertz model was used to estimate the biogas production in the anaerobic digestion system. ${ }^{25,26}$ The formula is as follows:

$$
P(t)=P_{\mathrm{m}} \times \exp \left\{-\exp \left[\frac{R_{\mathrm{m}} \times \mathrm{e}}{P_{\mathrm{m}}}(\lambda-t)+1\right]\right\}
$$

where $P_{(\mathrm{t})}$ is the cumulative gas production at time $t\left(\mathrm{~mL} \mathrm{~g}^{-1} \mathrm{VS}\right)$; $P_{\mathrm{m}}$ is the potential maximum gas yield ( $\left.\mathrm{mL} \mathrm{g}^{-1} \mathrm{VS}\right) ; R_{\mathrm{m}}$ is the maximum gas production rate (mg per VS per $\mathrm{d}$ ); $\lambda$ is the lag phase (d); $t$ is the duration of the assay (d) and e is $\exp (1)=$ 2.7183.

The bioavailability of heavy metals was expressed as $\alpha$, representing the ratio of $C_{(\mathrm{a})}$ and $C_{(\mathrm{t})}$. Specifically, $C_{(\mathrm{a})}$ is the sum of the concentrations of exchangeable $\left(C_{(1)}\right)$, carbonates $\left(C_{(2)}\right)$, ferromanganese oxides $\left(C_{(3)}\right)$ and organic compounds $\left(C_{(4)}\right)$, and $C_{(\mathrm{t})}$ is the sum of $C_{(\mathrm{a})}$ and the residual concentration $\left(C_{(5)}\right)$ in $\mathrm{mg}$ $\mathrm{kg}^{-1}$ (dry sludge) (eqn (2)-(4)). ${ }^{27}$

$$
C_{(\mathrm{a})}=C_{(1)}+C_{(2)}+C_{(3)}+C_{(4)}
$$




$$
\begin{gathered}
C_{(\mathrm{t})}=C_{(\mathrm{a})}+C_{(5)} \\
\alpha=\frac{C_{(a)}}{C_{(t)}}
\end{gathered}
$$

To measure the total amount of heavy metals, $0.2 \mathrm{~g}$ (accurate to $0.0001 \mathrm{~g}$ ) samples over 100 mesh sieves were digested in a mixture of $\mathrm{HNO}_{3}, \mathrm{HF}$ and $\mathrm{HClO}_{4}(5: 5: 3$, v/v/v). The contents of $\mathrm{Cu}$ and $\mathrm{Zn}$ were determined by inductively coupled plasma mass spectrometry (ICP-MS) (7700x, Agilent, USA). The fraction analysis of heavy metals was performed according to the procedures described in, ${ }^{27,28}$ in which $1 \mathrm{~g}$ (accurate to $0.0001 \mathrm{~g}$ ) sample over 100 mesh sieves was used with the five-step extraction method. The solution was diluted with $1 \% \mathrm{HNO}_{3}$ to $50 \mathrm{~mL}$, and the contents of $\mathrm{Cu}$ and $\mathrm{Zn}$ were measured by ICP-MS.

TS and VS were measured by the weight method. The total carbon and total nitrogen in the raw materials and inoculum were examined by an element analyzer (vario MACRO cube, Germany). The daily gas volume was determined by the saturated salt water method. ${ }^{29}$ Liquid samples of the anaerobic digestion were taken every two or three days, and the solution $\mathrm{pH}$ and COD were individually measured by a pH meter (3C ProF, STARTER, China) and the potassium dichromate oxidation method, respectively. The contents of the aqueous VFAs were determined by gas chromatography (7890A, Agilent, USA) coupled with an FID detector. The contents of $\mathrm{NH}_{4}{ }^{+}-\mathrm{N}$ in solution were measured by the traditional method. ${ }^{30}$ The percentage of methane gas was measured by a gas chromatograph coupled with a TCD detector (7890A, Agilent, USA). The morphologies and structures of the residual states of the heavy metals were analyzed via SEM (EVO18, ZEISS, Germany) with EDX spectroscopy (XM2, Genesis, USA). The XRD (D8-FOCUS, Bruker, Germany) patterns were acquired on a powder diffraction system with $\mathrm{Cu} \mathrm{K} \alpha$ radiation at $40 \mathrm{kV}, 40 \mathrm{~mA}$. The samples were scanned from $5^{\circ}$ to $80^{\circ}$ with a scan speed of $2^{\circ} \mathrm{min}^{-1}$.

The seed germination index (GI) is considered to be the most sensitive parameter for the toxicity evaluation of anaerobic digesting mixtures. ${ }^{31}$ In the present study, 10 Chinese cabbage seeds were placed on gauze moistened with the extracted liquid from the digests. The extract was obtained by adding $50 \mathrm{~mL}$ water to $5 \mathrm{~g}$ digests, followed by agitating at $200 \mathrm{rpm}$ for $1 \mathrm{~h}$ and filtration. The cultures were carried out at $25^{\circ} \mathrm{C}$ for $48 \mathrm{~h}$, and the germination rates and root lengths of the seedlings were measured. The GI value was calculated using eqn (5). ${ }^{32}$ The control group was treated with deionized water.

$$
\mathrm{GI}(\%)=\frac{\mathrm{SG}(\%) \times \mathrm{RL}_{\mathrm{T}}}{\mathrm{SG}(\%) \times \mathrm{RL}_{\mathrm{C}}} \times 100
$$

where $S G, R_{T}$ and $R_{C}$ represent the seed germination, root length of the treated seed and root length of the control, respectively.

\section{Statistical analysis}

All experimental values were expressed as the means \pm standard deviation (SD). Statistical analysis was performed using the
SPSS 19.0 statistical package (Chicago, USA). Statistical differences among different groups were analyzed using one-way analysis of variance (ANOVA) and Dunnett's tests with the significance level set as $p<0.05$. The XRD pattern phase identification and analysis results were processed by the analysis software Jade 6.0.

\section{QA/QC}

The reagents used in the experiments were all of excellent grade, and the experimental water was ultrapure water. A national soil reference material (GSS-3) was added for quality control. The recoveries of $\mathrm{Cu}$ and $\mathrm{Zn}$ were $86.96 \%$ to $112.45 \%$ and $80.27 \%$ to $118.78 \%$, respectively; each sample was parallelized by three groups, and three blanks were used for each batch of samples.

\section{Results and discussion}

\section{Characterization of $\mathrm{FA}$ and $\mathrm{Fe}_{3} \mathrm{O}_{4} / \mathrm{FA}$}

The micro-morphologies of $\mathrm{FA}$ and $\mathrm{Fe}_{3} \mathrm{O}_{4} / \mathrm{FA}$ were characterized by SEM images (Fig. 1A and B). As shown in Fig. 1A, FA consisted of ball-like particles with different sizes. Most of the particles were broken into pieces, and the surface became coarse after surface coprecipitation with $\mathrm{Fe}_{3} \mathrm{O}_{4}$ (Fig. 1B). EDX analysis suggested that the content of $\mathrm{Fe}$ in FA was $4.43 \%$, which sharply increased to $19.89 \%$ in $\mathrm{Fe}_{3} \mathrm{O}_{4} / \mathrm{FA}$ composites. XRD analysis also confirmed the successful synthesis of the composites. It was observed that quartz (marked by Q, JCPDS No. 33-1161) was the main mineral composition of FA (Fig. 1C). ${ }^{33}$ After coating with $\mathrm{Fe}_{3} \mathrm{O}_{4}$ (marked by $\mathrm{M}$ ), three sharp peaks at $2 \theta=35.570^{\circ}(311), 43.191^{\circ}(400)$ and $62.928^{\circ}$ (662) were strengthened in the diffraction pattern of $\mathrm{Fe}_{3} \mathrm{O}_{4} / \mathrm{FA} ;{ }^{34}$ these peaks match well with the standard spinel structure (JCPDS No. 89-3854). Compared with the initial FA, the diffraction line was much smoother and the small diffraction peaks disappeared after loading $\mathrm{Fe}_{3} \mathrm{O}_{4}$, indicating that the $\mathrm{Fe}_{3} \mathrm{O}_{4} / \mathrm{FA}$ composite has a higher degree of crystal order than FA.

\section{Effects of $\mathrm{Fe}_{3} \mathrm{O}_{4} / \mathrm{FA}$ on biogas production during anaerobic digestion}

The daily biogas yield, cumulative gas yield and cumulative volume of methane produced during anaerobic digestion of pig manure are shown in Fig. 2. The daily biogas production increased rapidly during 6 days of anaerobic digestion (Fig. 2A). Two peaks of the biogas yields were observed. The first peak for $0.5 \% \mathrm{Fe}_{3} \mathrm{O}_{4} / \mathrm{FA}, 1.0 \% \mathrm{Fe}_{3} \mathrm{O}_{4} / \mathrm{FA}$ and $\mathrm{CK}$ was found on the 6 th day, and the values were $2460 \mathrm{~mL}, 1563 \mathrm{~mL}$ and $2132 \mathrm{~mL}$, respectively. The second peak appeared on the 10th day, with individual values of $2418 \mathrm{~mL}, 2832 \mathrm{~mL}$ and $3183 \mathrm{~mL}$, respectively. Two peaks of the daily biogas yield of $2.5 \% \mathrm{Fe}_{3} \mathrm{O}_{4} / \mathrm{FA}$ were recorded on the 8 th day $(2725 \mathrm{~mL})$ and 13 th day $(1410 \mathrm{~mL})$. It may thus be inferred that a high concentration of $\mathrm{Fe}_{3} \mathrm{O}_{4} / \mathrm{FA}$ exhibits adverse effects on anaerobic digestion and leads to postponement of the gas production peak in anaerobic digestion, as previously mentioned by Yang et $a .^{35}$ The substrate of digestion is consumed continuously following anaerobic digestion, contributing to the decreased biogas production after the second peak of gas production. The difference in the daily outputs among all the 

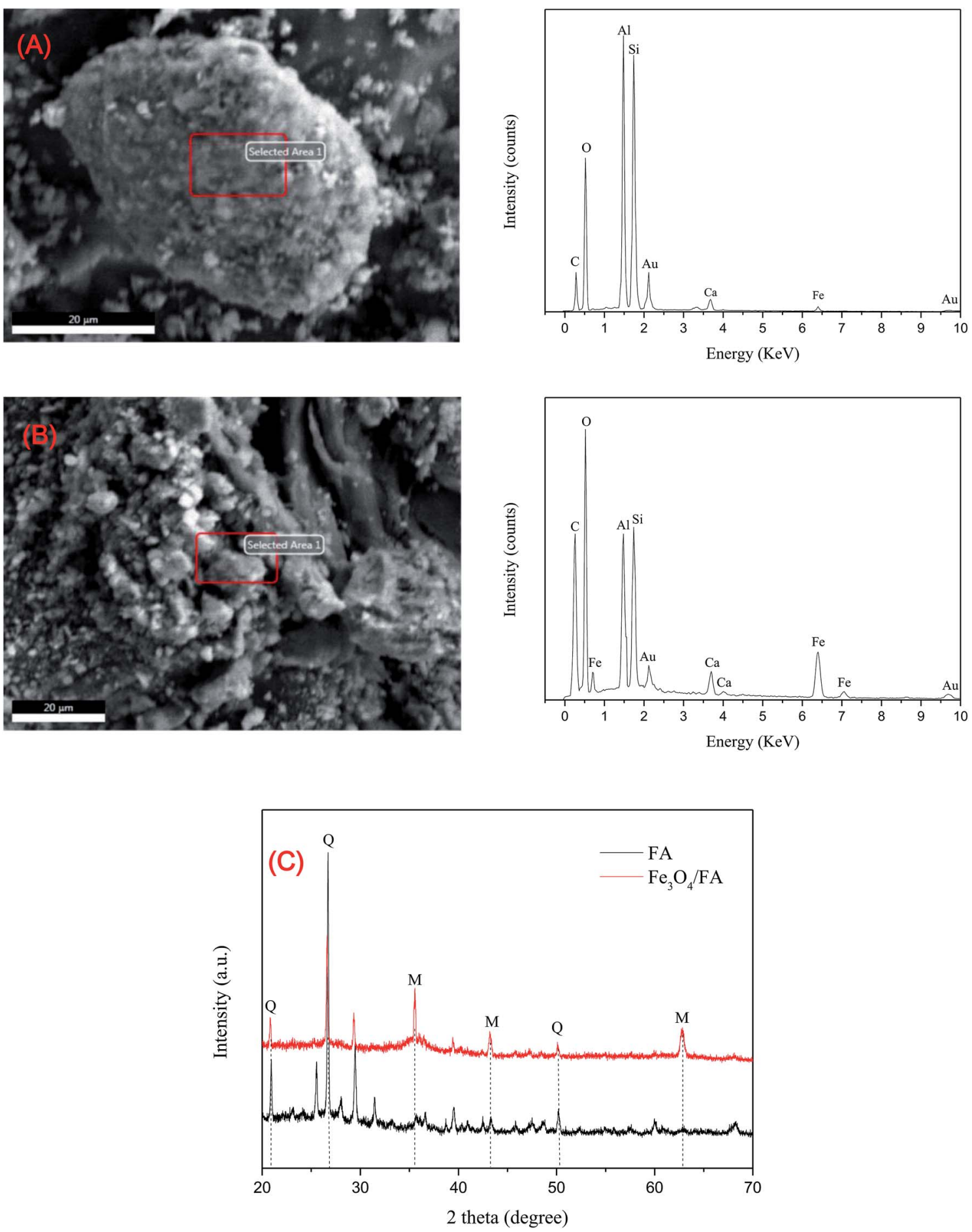

Fig. 1 Characterization of $\mathrm{FA}$ and $\mathrm{Fe}_{3} \mathrm{O}_{4} / \mathrm{FA}$. (A), SEM image and EDX spectrum of $\mathrm{FA}$; (B), SEM image and EDX spectrum of Fe ${ }_{3} \mathrm{O}_{4} / \mathrm{FA}$; (C), XRD patterns of $\mathrm{FA}$ and $\mathrm{Fe}_{3} \mathrm{O}_{4} / \mathrm{FA}$.

experimental groups decreased with time. The gas production was also decreased on completion of 35 days of digestion.

The cumulative volume of biogas produced during anaerobic digestion is shown in Fig. 2B. The total volumes of biogas were $180.27,166.70,167.33$ and $158.38 \mathrm{~mL} \mathrm{~g}^{-1} \mathrm{VS}$ in the digesters with $0.5 \%, 1.0 \%, 2.5 \% \mathrm{Fe}_{3} \mathrm{O}_{4} / \mathrm{FA}$ and $\mathrm{CK}$, respectively. The results suggested that the production of biogas was increased after the addition of $\mathrm{Fe}_{3} \mathrm{O}_{4} / \mathrm{FA}$ compared to the control, implying obvious stimulation of the biogas by these composites. The increased gas production may be due to the presence of $\mathrm{Fe}_{3} \mathrm{O}_{4}$, which plays a critical role in enhancing the syntrophic/cooperative metabolism between electron-donating and electron-accepting microorganisms via direct interspecies electron transfer processes. ${ }^{36,37}$ Gao et al. reported that $\mathrm{Ca}^{2+}$ was necessary for the formation of methanogens and microbial aggregates during anaerobic digestion. ${ }^{38}$ The $\mathrm{Ca}^{2+}$ released from $\mathrm{CaO}$ in $\mathrm{FA}$ during anaerobic 

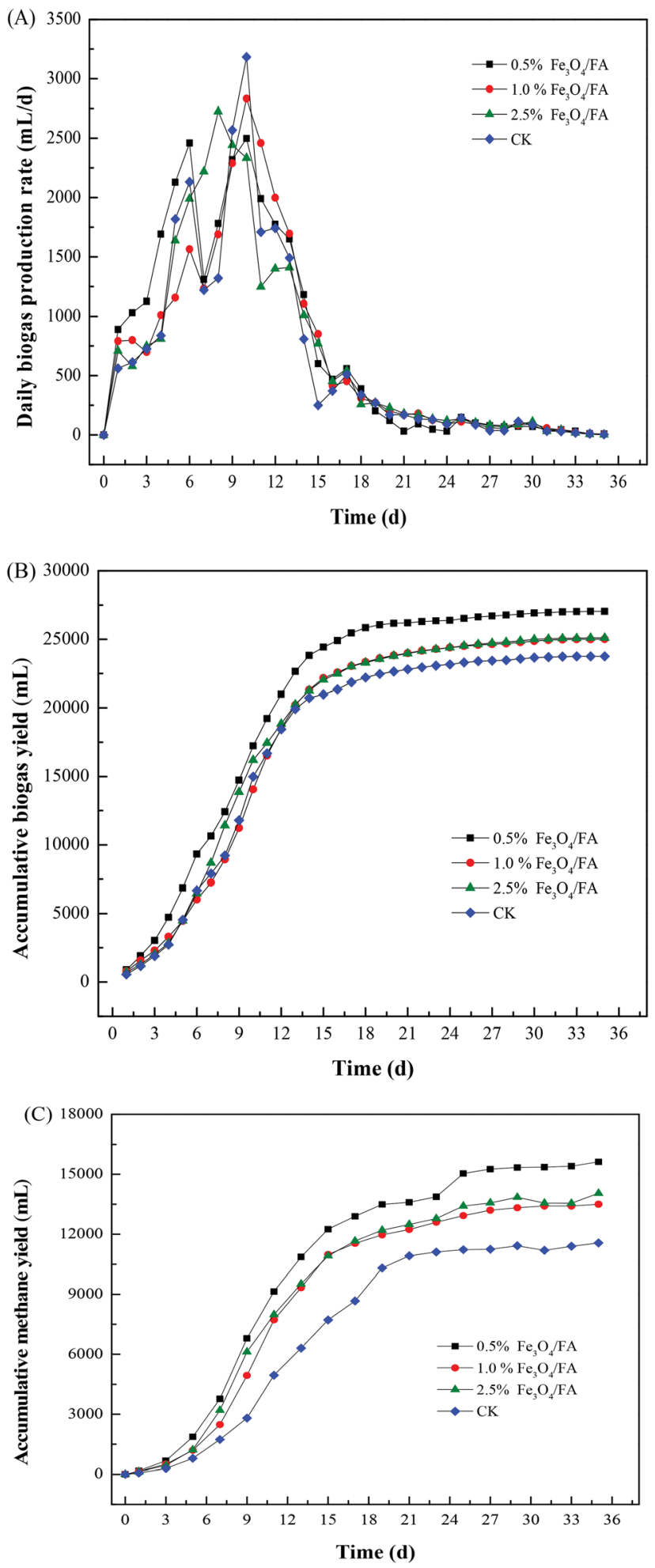

Fig. 2 Daily biogas production (A), cumulative biogas yields (B) and cumulative volume of methane (C) produced within 35 days of anaerobic digestion with and without $\mathrm{Fe}_{3} \mathrm{O}_{4} / \mathrm{FA}$.

digestion may also function to increase biogas generation. Moreover, we found that the addition of low concentrations of $\mathrm{Fe}_{3} \mathrm{O}_{4} / \mathrm{FA}$ significantly stimulated anaerobic digestion, whereas the biogas yields decreased with increasing dose of $\mathrm{Fe}_{3} \mathrm{O}_{4} / \mathrm{FA}$.
Similar phenomena were reported by Suanon, ${ }^{24}$ in which the total gas production induced by $0.5 \%$ nanometer $\mathrm{ZVI}$ and $0.5 \% \mathrm{Fe}_{3} \mathrm{O}_{4}$ was higher than that by $1 \%$ nanometer $\mathrm{ZVI}$ and $1 \% \mathrm{Fe}_{3} \mathrm{O}_{4}$ during anaerobic digestion of sludge.

As a key parameter for assessing anaerobic digestion, the biogas production (mainly methane gas production) was recorded every two days (Fig. 2C). The values of the accumulative methane yields were 120.16, 103.85, 108.08 and $88.92 \mathrm{~mL} \mathrm{~g}^{-1}$ VS for $0.5 \%, 1.0 \%$, $2.5 \% \mathrm{Fe}_{3} \mathrm{O}_{4} / \mathrm{FA}$ and $\mathrm{CK}$, respectively. Comparatively, the methane yield observed in this work is higher than that of anaerobic digestion of pig manure for 20 days $\left(62.50 \mathrm{~mL} \mathrm{~g}^{-1} \mathrm{VS} \text { added }\right)^{39}$ and in anaerobic digestion of sludge for 12 days $\left(47.18\right.$ to $84.27 \mathrm{~mL} \mathrm{~g}^{-1}$ added VS). ${ }^{24}$ However, the methane yield in the present study is lower than the results reported by Ferreira et al., who found that the methane yield of the raw pig manure after anaerobic digestion was about $159 \mathrm{~mL} \mathrm{~g}^{-1}$ added VS. ${ }^{40}$ This can be attributed to the longer storage time and the lower moisture content of pig manure than those used in this work, which may lead to slow growth of the fermented microorganisms. In addition, fresh pig manure contains large amounts of livestock and poultry urine, which possess large amounts of COD. Therefore, the methane produced during anaerobic fermentation may be decomposed from organic matter in urine and feces; thus, the methane yields in these studies are higher than those in our study. Compared with the control, the methane contents increased by $16.78 \%$ to $35.13 \%$ after addition of $\mathrm{Fe}_{3} \mathrm{O}_{4} / \mathrm{FA}$, which further demonstrates its enhancing effects on the anaerobic digestion of pig manure.

\section{Kinetic analysis}

Modified Gompertz equations were used to fit the data of the biogas production and methanogenesis processes. The $R^{2}$ values were $>0.99$ for all groups (Table 2), indicating good fitness. The addition of $\mathrm{Fe}_{3} \mathrm{O}_{4} / \mathrm{FA}$ could significantly increase the methane yield $(p<0.05)$ at its optimal ratio of $0.5 \%$. The gas production rate decreased with increasing $\mathrm{Fe}_{3} \mathrm{O}_{4} / \mathrm{FA}$ dosage (Table 2). Therefore, an appropriate concentration of $\mathrm{Fe}_{3} \mathrm{O}_{4} / \mathrm{FA}$ can significantly promote methane production during anaerobic digestion. Moreover, the delay period of anaerobic digestion was shortened after addition of $\mathrm{Fe}_{3} \mathrm{O}_{4} / \mathrm{FA}$. This is mainly due to stimulation of the electric syntrophy effect between propionate-oxidizing bacteria and methanogens via $\mathrm{Fe}_{3} \mathrm{O}_{4}$ particles, which greatly improves the degradation rate of organic acids and the methanogenesis of propionic acid. ${ }^{\mathbf{4 1 - 4 3}}$

\section{Changes of physicochemical properties during anaerobic digestion}

The variations of $\mathrm{pH}$ during anaerobic digestion of pig manure are shown in Fig. 3A. In the first 5 days, the $\mathrm{pH}$ value of each fermenting tank rapidly decreased from 8.0 to 6.7, and $\mathrm{Fe}_{3} \mathrm{O}_{4} / \mathrm{FA}$ addition slowed the extent of the $\mathrm{pH}$ decrease (Fig. 3A). The anaerobic corrosion of $\mathrm{Fe}_{3} \mathrm{O}_{4} / \mathrm{FA}$ could generate $\mathrm{OH}^{-}$, thereby increasing the buffering capacity. ${ }^{\mathbf{4 4 , 4 5}}$

The rapid decline of $\mathrm{pH}$ is due to the accumulation of COD and VFAs (Fig. 3B and $\mathrm{C}$ ). The maximum $\mathrm{COD}$ values reached $6320 \mathrm{mg} \mathrm{L}^{-1}$ for $0.5 \% \mathrm{Fe}_{3} \mathrm{O}_{4} / \mathrm{FA}, 6156 \mathrm{mg} \mathrm{L}^{-1}$ for $1.0 \% \mathrm{Fe}_{3} \mathrm{O}_{4} /$ FA, $5492 \mathrm{mg} \mathrm{L}^{-1}$ for $2.5 \% \mathrm{Fe}_{3} \mathrm{O}_{4} / \mathrm{FA}$, and $4952 \mathrm{mg} \mathrm{L}^{-1}$ for CK 
Table 2 Kinetics results obtained by the modified Gompertz model

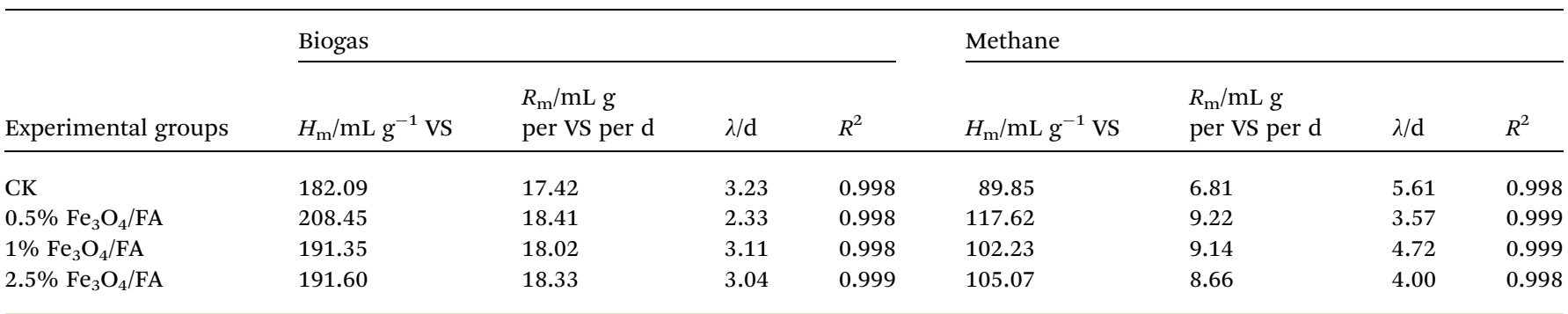

after 5 days of reaction. The additive activation enhanced the anaerobic digestion; the resulting COD values of the $\mathrm{Fe}_{3} \mathrm{O}_{4} / \mathrm{FA}$ added groups were higher than that of the CK group.
Gradually, the COD values in all experimental treatments showed a decreasing trend with further anaerobic digestion (after the 5th day).
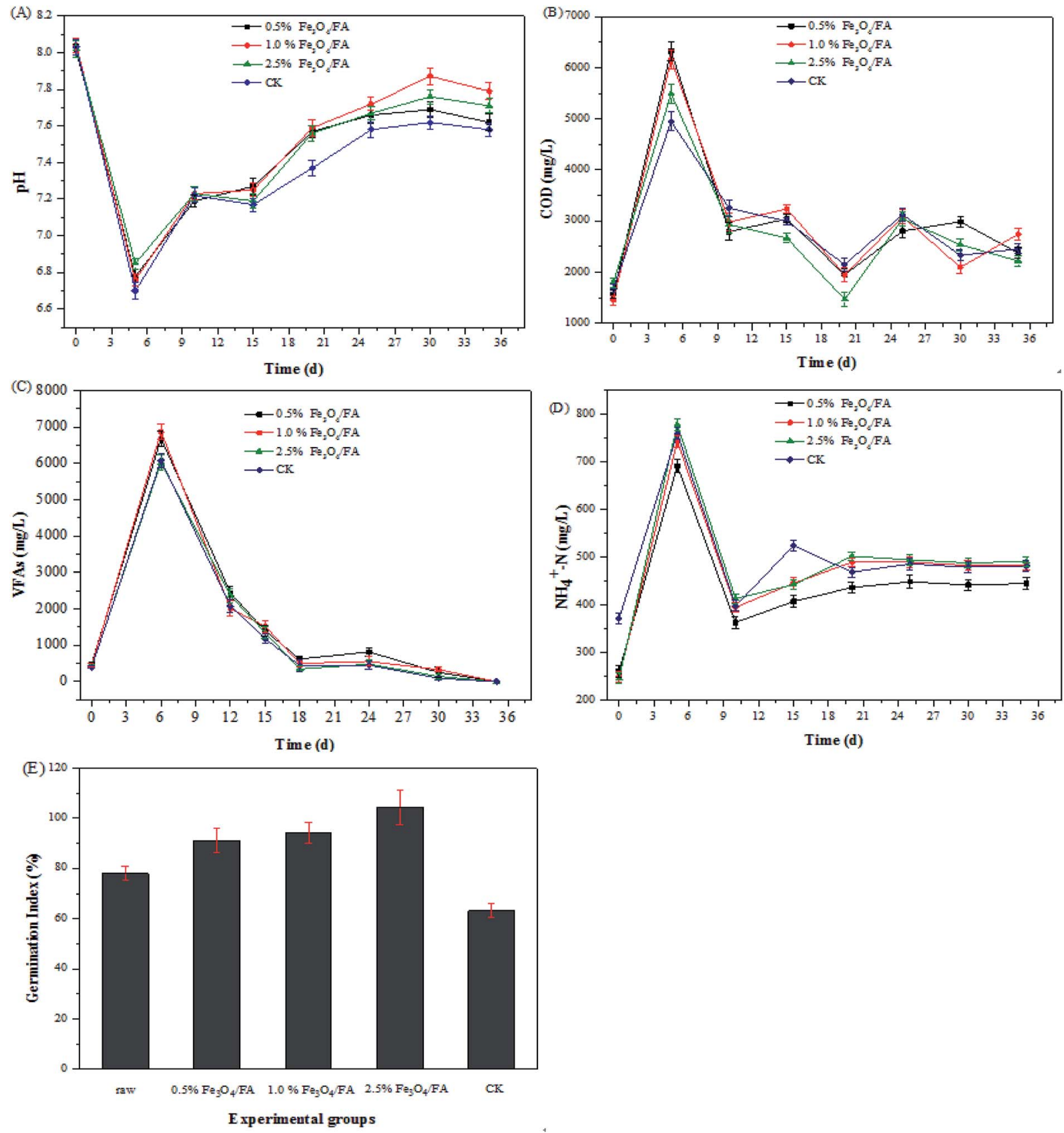

Fig. 3 Effects of different concentrations of $\mathrm{Fe}_{3} \mathrm{O}_{4} / \mathrm{FA}$ on (A) $\mathrm{pH}$, (B) COD, (C) VFAs, (D) $\mathrm{NH}_{4}{ }^{+}-\mathrm{N}$ and (E) Gl value during anaerobic digestion. 
The contents of VFAs reached the maximum values after 6 days of anaerobic digestion, i.e., 6685.16, 6875.88, 6035.65 and $6088.32 \mathrm{mg} \mathrm{L}^{-1}$ for the $0.5 \%, 1.0 \%$, and $2.5 \% \mathrm{Fe}_{3} \mathrm{O}_{4} / \mathrm{FA}$ groups and the CK group, respectively. The biogas digestion process was suppressed when the content of VFAs was greater than $6 \mathrm{~g}$ $\mathrm{L}^{-1}{ }^{\mathbf{4 6}}$ Therefore, there was no acid inhibition in this experiment. Ammonium nitrogen $\left(\mathrm{NH}_{4}{ }^{+}-\mathrm{N}\right)$ can inhibit microbial activity in pig manure anaerobic digestion. ${ }^{47}$ The contents of ammonium nitrogen ranged from 200 to $800 \mathrm{mg} \mathrm{L}^{-1}$ for the four experimental groups (Fig. 3D). The content of $\mathrm{NH}_{4}{ }^{+}-\mathrm{N}$ had no antagonistic effect on anaerobic bacteria in the range of 200 to $1000 \mathrm{mg} \mathrm{L}^{-1}$; $^{48}$ therefore, there was no inhibition of $\mathrm{NH}_{4}{ }^{+}-\mathrm{N}$ during anaerobic digestion of pig manure in this work.

In addition, the phytotoxic effects of the final digest product were evaluated using the seed germination test. A GI value greater than $50 \%$ was used as an indicator of the phytotoxic-free compost, ${ }^{49}$ and a GI value greater than $80 \%$ was considered to indicate the mature compost. ${ }^{50}$ As presented in Fig. 3E, the seed GI was in the range of $91.18 \%$ to $104.41 \%$ for the three groups with addition of $\mathrm{Fe}_{3} \mathrm{O}_{4} / \mathrm{FA}$, which is higher than the ranges of the raw $(77.94 \%)$ and $\mathrm{CK}$ groups (63.24\%). These results indicate that the addition of appropriate contents of $\mathrm{Fe}_{3} \mathrm{O}_{4} / \mathrm{FA}$ can improve the quality of digest.

\section{Passivation of $\mathrm{Cu}$ and $\mathrm{Zn}$ during anaerobic digestion}

Our results demonstrated that $\mathrm{Cu}$ and $\mathrm{Zn}$ were released into the liquid phase during anaerobic digestion of pig manure (Fig. 4). The aqueous concentrations of $\mathrm{Cu}$ and $\mathrm{Zn}$ in the $\mathrm{CK}$ group were 1.846 and $8.919 \mathrm{mg} \mathrm{L}^{-1}$, respectively, suggesting that $17.25 \% \mathrm{Cu}$ and $11.93 \% \mathrm{Zn}$ remained in the liquid phase. Comparatively, less than $10 \%$ of these two heavy metals in all of the experimental groups with $\mathrm{Fe}_{3} \mathrm{O}_{4} / \mathrm{FA}(0.5 \%, 1.0 \%$ and $2.5 \%)$ were released into the solution (Fig. 4). The release of metals in the solution can be attributed to the decomposition of organic matter and related compounds in pig manure. ${ }^{51-53}$ Because only very low concentrations of $\mathrm{Cu}$ and $\mathrm{Zn}$ were detected in the liquid phase, the metals appeared to be immobilized within the pig manure in the groups with $0.5 \%, 1.0 \%$ and $2.5 \% \mathrm{Fe}_{3} \mathrm{O}_{4} / \mathrm{FA}$

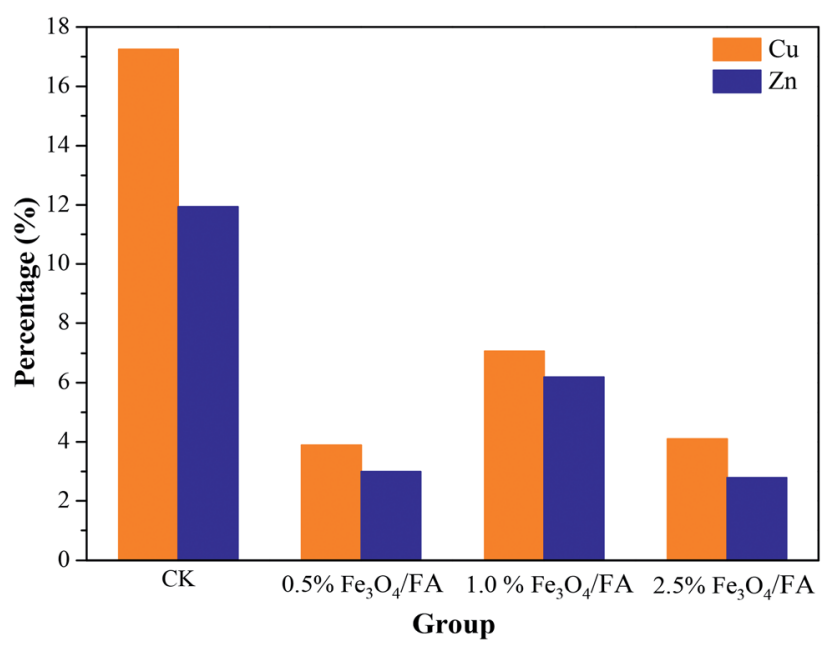

Fig. 4 The contents of $\mathrm{Cu}$ and $\mathrm{Zn}$ in the liquid phase.
(Fig. 4). This may be due to the good adsorption properties of the $\mathrm{Fe}_{3} \mathrm{O}_{4} / \mathrm{FA}$ added during digestion and the formation of a hydrated oxide covering layer on the surface of the particles, which enhanced the adsorption of heavy metal ions. ${ }^{54,55}$ The release rates of $\mathrm{Cu}$ are higher than that of $\mathrm{Zn}$ (Fig. 4). Heavy metals have inhibitory effects on anaerobic digestion, ${ }^{56}$ and previous studies suggested that biogas production is severely affected when using concentrations of $\mathrm{CuO}$ and $\mathrm{ZnO}$ nanoparticles greater than $15 \mathrm{mg} \mathrm{L}^{-1}$ and $120 \mathrm{mg} \mathrm{L}^{-1}$, respectively. ${ }^{56}$ Our results indicated that a higher concentration of $\mathrm{Fe}_{3} \mathrm{O}_{4} / \mathrm{FA}$ added during digestion can decrease the release of $\mathrm{Cu}$ and $\mathrm{Zn}$ and therefore result in lower potential inhibitory effects on microbial activity during anaerobic digestion.

The concentrations of $\mathrm{Cu}$ and $\mathrm{Zn}$ in the solid mixture were 273.43 and $1916.30 \mathrm{mg} \mathrm{kg} \mathrm{kg}^{-1}$ before anaerobic digestion, respectively. After 35 days of anaerobic digestion, the concentrations of $\mathrm{Cu}$ and $\mathrm{Zn}$ in the solid phase were within the ranges of 295.21 to 352.35 and 2067.65 to $2431.61 \mathrm{mg} \mathrm{kg}^{-1}$, respectively, i.e., about 1.08 to 1.29 and 1.08 to 1.27 times those in the initial solid mixtures. These results suggest a significant "relative concentration effect", ${ }^{57}$ and the increased concentrations of heavy metals after anaerobic digestion may be due to the consumption of organic matter. ${ }^{58}$

According to Tessier et al., ${ }^{28}$ the speciation of heavy metals can be divided into five types: (1) the exchangeable fraction, which is the most easily released into the environment, resulting in heavy metal pollution; (2) the carbonate fraction, which is sensitive to $\mathrm{pH}$ and readily released into the environment at low $\mathrm{pH}$; (3) the Fe-Mn oxide-bound fraction; (4) the organic combination state, which is not stable when the redox conditions are changed; (5) the residual fraction, which is the most stable. The fraction distributions of $\mathrm{Cu}$ and $\mathrm{Zn}$ after anaerobic digestion are shown in Fig. 5; Cu was mainly present in organic matter, and its levels increased from $56.24 \%$ (in the initial pig manure) to $62.68 \%$ to $73.17 \%$ (after anaerobic digestion) (Fig. 5A), which may be due to the high affinity of $\mathrm{Cu}$ to humic acids during anaerobic digestion. ${ }^{\mathbf{5 9 , 6 0}}$ Previous studies suggested that $\mathrm{Cu}$ can be immobilized by complexation and chelation with organic matter, which decreased the bioavailability of $\mathrm{Cu}$ to crops. ${ }^{61}$ Compared with raw pig manure, the contents of the exchangeable, carbonate, and $\mathrm{Fe}-\mathrm{Mn}$ oxide fractions of $\mathrm{Cu}$ all decreased in the solid phase after anaerobic digestion. Meanwhile, compared to the CK group, the residual fraction of $\mathrm{Cu}$ significantly increased, i.e., from $22.28 \%$ for $\mathrm{CK}$ to $22.28 \%$ to $30.55 \%$ for the three groups with the addition of $\mathrm{Fe}_{3} \mathrm{O}_{4} / \mathrm{FA}(p<0.05)$. Moreover, the residual state increased with increasing addition of $\mathrm{Fe}_{3} \mathrm{O}_{4} / \mathrm{FA}$. Therefore, the present results indicate that addition of $\mathrm{Fe}_{3} \mathrm{O}_{4} / \mathrm{FA}$ can decrease the bioavailability of $\mathrm{Cu}$ during anaerobic digestion of pig manure.

Additionally, the effects of different concentrations of $\mathrm{Fe}_{3} \mathrm{O}_{4} /$ FA on the morphology of $\mathrm{Zn}$ are presented in Fig. 5B. Zn were mainly distributed in the Fe-Mn oxide-bound fraction, i.e., $64.75 \%, 75.13 \%, 74.92 \%, 76.33 \%$ and $69.90 \%$ for raw pig mature with $0.5 \%, 1.0 \%$, and $2.5 \% \mathrm{Fe}_{3} \mathrm{O}_{4} / \mathrm{FA}$ and $\mathrm{CK}$, respectively. Compared with the $\mathrm{CK}$, the residual state of $\mathrm{Zn}$ in the biogas residue increased remarkably $(p<0.05)$, and the 


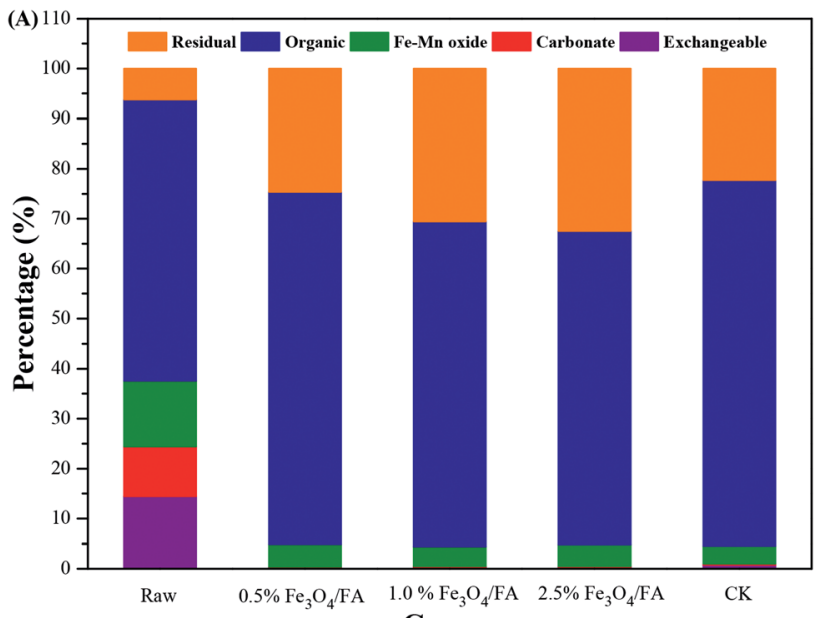

Groups

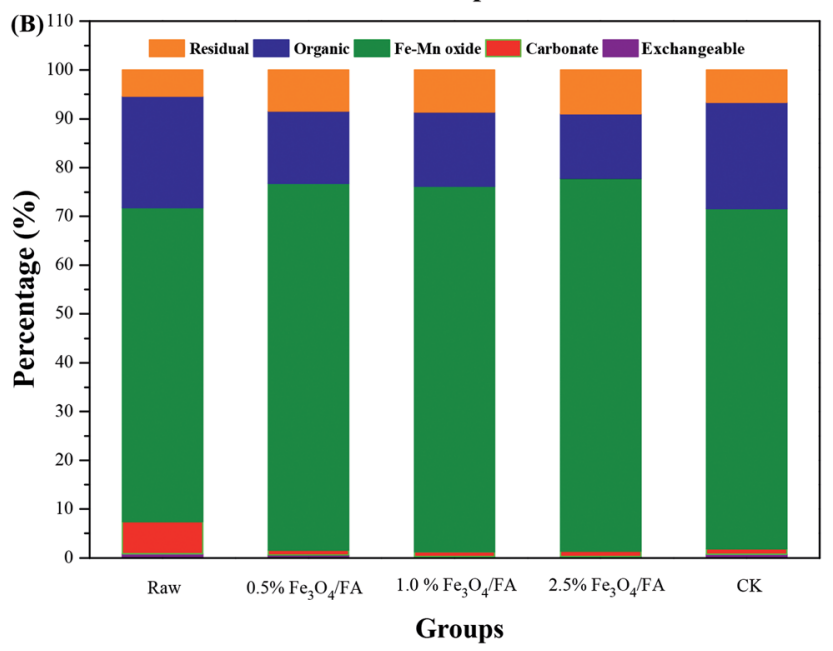

Fig. 5 Chemical fractionation of $\mathrm{Cu}(\mathrm{A})$ and $\mathrm{Zn}(\mathrm{B})$.

additions of $2.5 \%$ and $0.5 \% \mathrm{Fe}_{3} \mathrm{O}_{4} / \mathrm{FA}$ increased it the most $(42.14 \%)$ and the least $(33.49 \%)$, respectively.

The value of $\alpha$ was calculated by eqn (4) and can reflect the bioavailability of $\mathrm{Cu}$ and $\mathrm{Zn}$. As shown in Fig. 6, the bioavailability of $\mathrm{Cu}$ and $\mathrm{Zn}$ decreased compared to the initial pig manure, and the values decreased from 0.94 to 0.68 to 0.78 for $\mathrm{Cu}$ and from 0.95 to 0.91 to 0.93 for $\mathrm{Zn}$. The $\alpha$ values of $\mathrm{Cu}$ and $\mathrm{Zn}$ in the $\mathrm{Fe}_{3} \mathrm{O}_{4} / \mathrm{FA}$-treated groups individually decreased by $3.08 \%$ to $13.12 \%$ and $1.93 \%$ to $2.52 \%$ compared with CK. Moreover, the bioavailability of $\mathrm{Cu}$ was more obvious than that of $\mathrm{Zn}$.

The above results indicate that the use of $\mathrm{Fe}_{3} \mathrm{O}_{4} / \mathrm{FA}$ under anaerobic digestion conditions can effectively decrease the contents of highly reactive $\mathrm{Cu}$ and $\mathrm{Zn}$ (exchangeable fraction and carbonate fraction) and increase the residue content with the lowest activity. Moreover, the passivation effect is more obvious with higher concentrations of $\mathrm{Fe}_{3} \mathrm{O}_{4} / \mathrm{FA}$. This may be due to the adsorption and alkaline effects of the fly ash surface ${ }^{62}$ and the direct interspecies electron transfer of $\mathrm{Fe}_{3} \mathrm{O}_{4} / \mathrm{FA}$ particles supported on the surface of fly ash to enhance the biodegradation of organic matter, thereby changing the distribution of $\mathrm{Cu}$ and $\mathrm{Zn}$. The increased content of residual $\mathrm{Cu}$ and

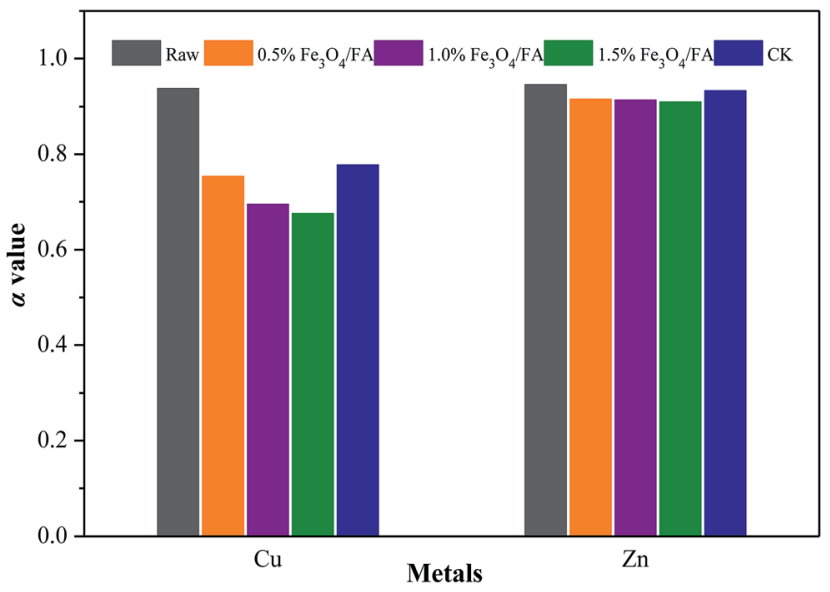

Fig. 6 Variation of $\alpha$ values before and after anaerobic digestion.

Zn enhanced the passivation effect and decreased their bioavailability.

\section{Characterization of the residual fractions of $\mathrm{Cu}$ and $\mathrm{Zn}$ during anaerobic digestion}

In order to reveal the possible mechanism of heavy metal passivation during anaerobic digestion, XRD was performed to determine the mineral phases of the heavy metal residue fractions before and after anaerobic digestion. As shown in Fig. 7, the heavy metal residue fractions of the initial pig manure (raw), CK and $2.5 \% \mathrm{Fe}_{3} \mathrm{O}_{4} / \mathrm{FA}$-treated groups were analyzed. The results suggest that the mineral phases in the residue fractions of the three groups were mainly silicate minerals. The XRD maps of the heavy metal residues of each group are very similar. Compared to the XRD map of the raw sample, the peaks at $2 \theta=$ $14.280^{\circ}(d=0.619 \mathrm{~nm}), 26.610^{\circ}(d=0.334 \mathrm{~nm}), 27.499^{\circ}(d=$ $0.324 \mathrm{~nm}), 59.949^{\circ}(d=0.154 \mathrm{~nm})$ and $68.121^{\circ}(d=0.137 \mathrm{~nm})$ were obviously weakened in the residue fractions of the CK and $2.5 \% \mathrm{Fe}_{3} \mathrm{O}_{4} / \mathrm{FA}$ groups. The above five peaks were attributed to $\mathrm{CaCO}_{3},\left(\mathrm{~K}, \mathrm{H}_{3} \mathrm{O}\right) \mathrm{Al}_{2} \mathrm{Si}_{3} \mathrm{AlO}_{10}(\mathrm{OH})_{2}, \mathrm{Ca}_{2} \mathrm{SiO}_{4}, \mathrm{CaMgSiO}_{4}$ and $\mathrm{SiO}_{2}$ via phase identification, respectively. Hydrolysis of these minerals during anaerobic digestion may result in decreased

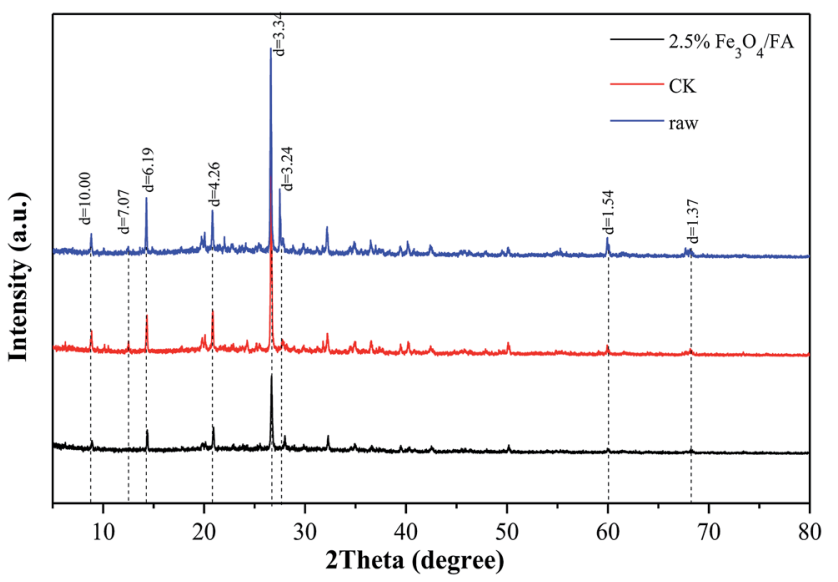

Fig. 7 Powder XRD patterns of heavy metal residues before and after anaerobic digestion. 
self-activity. Compared with the XRD spectrum of the Raw sample, the peak intensities of $2 \theta=8.830^{\circ}(d=1.000 \mathrm{~nm})$ and $12.500^{\circ}(d=0.707 \mathrm{~nm})$, representing $\left(\mathrm{K}_{3} \mathrm{H}_{3} \mathrm{O}\right) \mathrm{Al}_{2} \mathrm{Si}_{3} \mathrm{AlO}_{10}(\mathrm{OH})_{2}$ and $\mathrm{K}_{2} \mathrm{Mg}_{2} \mathrm{Si}_{2} \mathrm{O}_{30}$, respectively, in the residues of the $\mathrm{Fe}_{3} \mathrm{O}_{4} / \mathrm{FA}^{-}$ treated groups were obviously decreased. It was speculated that the addition of $\mathrm{Fe}_{3} \mathrm{O}_{4} / \mathrm{FA}$ partly improves the hydrolysis of these clay minerals and thus transforms them into more stable minerals. In addition, a strong additional peak was located at $2 \theta$ $=28.009^{\circ}\left(d=0.318 \mathrm{~nm}\right.$, assigning as $\left.\mathrm{CaZnSiO}_{4} \mathrm{H}_{2} \mathrm{O}\right)$. The silicate was wrapped with low-solubility minerals by physical adsorption with the addition of $\mathrm{Fe}_{3} \mathrm{O}_{4} / \mathrm{FA}$ composites in the anaerobic fermenting tank. However, we could not detect $\mathrm{Cu}$ minerals in the XRD analysis; this may be because of the small amount of $\mathrm{Cu}$ for the formation of new amorphous metallic minerals.
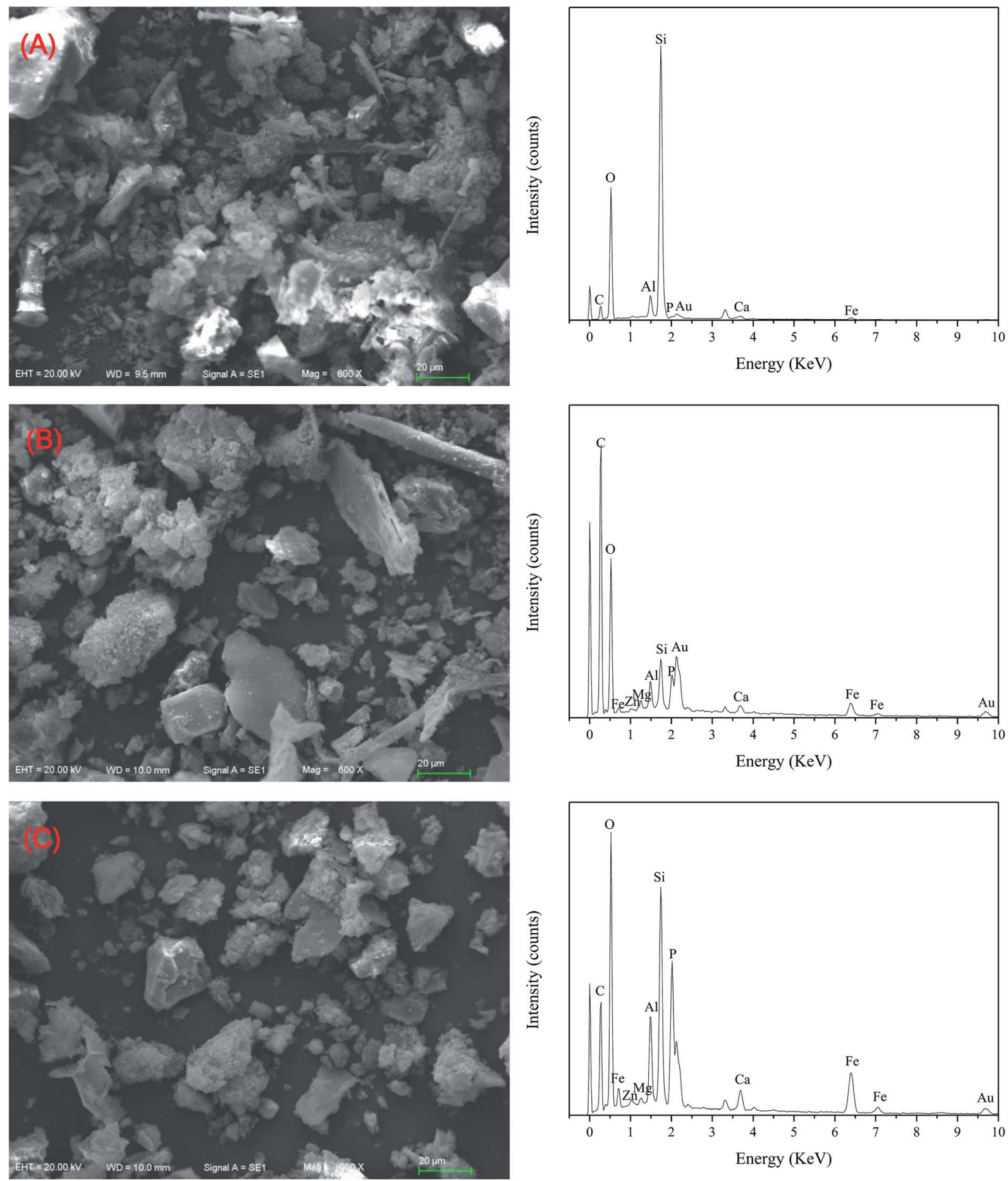

Fig. 8 SEM-EDX images of the heavy metal residues before and after anaerobic digestion. (A) Initial pig manure (raw); (B) digester blank control (CK); (C) digester $2.5 \% \mathrm{Fe}_{3} \mathrm{O}_{4} / \mathrm{FA}$. 
SEM-EDX was also used to observe the residual states of $\mathrm{Cu}$ and $\mathrm{Zn}$ before and after anaerobic digestion (Fig. 8). The results showed that the surface of the residue state was smoother after anaerobic digestion, and the treatment with $2.5 \% \mathrm{Fe}_{3} \mathrm{O}_{4} / \mathrm{FA}$ was more obvious (Fig. 8C). This is probably due to the fact that the silicate minerals formed by heavy metals and other unknown crystals produced a surface coating on the residue during anaerobic digestion; they can also cover the heavy metal ions and prevent their leakage. In addition, EDX analysis showed that $\mathrm{Cu}$ and $\mathrm{Zn}$ were observed on the surface of the solid sample after anaerobic digestion. Compared with the initial pig manure, the contents of $\mathrm{Cu}$ and $\mathrm{Zn}$ were increased in the $\mathrm{Fe}_{3} \mathrm{O}_{4}$ / FA-treated group, and the highest values of the two metals were found in the $2.5 \% \mathrm{Fe}_{3} \mathrm{O}_{4} / \mathrm{FA}$-treated group. Therefore, it can be inferred that the passivation mechanism of the $\mathrm{Fe}_{3} \mathrm{O}_{4} / \mathrm{FA}$ composites mainly via physical adsorption of $\mathrm{Fe}$ and Mn oxides in $\mathrm{Fe}_{3} \mathrm{O}_{4} /$ FA. This physical adsorption can transform heavy metals into metal minerals with poor solubility and migration properties.

\section{Conclusion and outlook}

In this work, the gas production and distribution of heavy metals were analyzed during anaerobic digestion of pig manure treated with $\mathrm{Fe}_{3} \mathrm{O}_{4} / \mathrm{FA}$ composite. Our results suggested that the addition of $\mathrm{Fe}_{3} \mathrm{O}_{4} / \mathrm{FA}$ with different concentrations could promote methane production in the anaerobic digestion system with the optimal dose of $0.5 \% \mathrm{Fe}_{3} \mathrm{O}_{4} / \mathrm{FA}$. The introduction of $\mathrm{Fe}_{3} \mathrm{O}_{4} / \mathrm{FA}$ composites could effectively control the mobilization of heavy metals; also, the concentrations of $\mathrm{Cu}$ and $\mathrm{Zn}$ increased after anaerobic digestion, presenting a significant "relative concentration effect". Morphological analysis suggested that the addition of $\mathrm{Fe}_{3} \mathrm{O}_{4} / \mathrm{FA}$ enhanced the passivation of $\mathrm{Cu}$ and $\mathrm{Zn}$ in the solid digested residues, i.e., the residual states of $\mathrm{Cu}$ and $\mathrm{Zn}$ were increased by $10.73 \%$ to $45.78 \%$ and $33.49 \%$ to $42.14 \%$, respectively. Moreover, better performance was observed in the treatment with $2.5 \% \mathrm{Fe}_{3} \mathrm{O}_{4} / \mathrm{FA}$.

XRD and SEM-EDX analysis demonstrated that the mechanism of $\mathrm{Fe}_{3} \mathrm{O}_{4} / \mathrm{FA}$ for passivating heavy metals mainly involves physical adsorption during the anaerobic digestion. It can convert heavy metals into stable mineral precipitates, decreasing the solubility and mobility of the heavy metals and thus effectively passivating them. These findings may be beneficial to provide a theoretical basis for decreasing the heavy metal activity of livestock manure and decreasing the risk of heavy metal release. More studies are needed to fully address the underlying mechanisms of heavy metal passivation.

\section{Conflicts of interest}

There are no conflicts to declare.

\section{Acknowledgements}

This work was supported by the National Water Pollution Control and Treatment Science and Technology Major Project in China (2017ZX07603002), National Natural Science
Foundation of China (No. 21607001 and 41172121), the Anhui Provincial Natural Science Foundation (No. 1608085QB45) and the Anhui Province Key Laboratory of Wetland Ecosystem Protection and Restoration (Anhui University).

\section{Notes and references}

1 Y. J. Shen, L. X. Zhao, H. B. Meng, Y. Q. Hou, H. B. Zhou, F. Wang, H. S. Cheng and H. B. Liu, Waste Manage. Res., 2016, 34, 578-583.

2 C. E. Marcato, E. Pinelli, M. F. Cecchi, P. Winterton and M. Guiresse, Ecotoxicol. Environ. Saf., 2009, 72, 1538-1544.

3 F. S. Zhang, Y. X. Li, M. Yang and W. Li, Int. J. Environ. Res. Public Health, 2012, 9, 2658-2668.

4 F. Wang, L. X. Zhao, Y. J. Shen, H. B. Meng, X. Xiang, H. S. Cheng and Y. Luo, Trans. Chin. Soc. Agric. Eng., 2013, 29, 202-208.

5 G. Q. Peng, G. M. Tian and J. Z. Liu, Desalination, 2011, 271, 100-104.

6 J. C. Shi, X. L. Yu, M. K. Zhang, S. G. Lu, W. H. Wu, J. J. Wu and J. M. Xu, J. Environ. Qual., 2011, 40, 1695-1704.

7 Y. Huang, H. Dong, B. Shang, H. Xin and Z. Zhu, Appl. Energy, 2011, 88, 947-952.

8 Y. Xu, W. Yu, Q. Ma and H. Zhou, Plant, Soil Environ., 2013, 59, 492-499.

9 B. Dong, X. G. Liu, L. Dai and X. Dai, Bioresour. Technol., 2013, 131, 152-158.

10 W. Liu, R. Huo, J. X. Xu, S. X. Liang, J. J. Li, T. K. Zhao and S. T. Wang, Bioresour. Technol., 2017, 235, 43-49.

11 T. T. T. Cu, P. H. Cuong, L. T. Hang, N. V. Chao, L. X. Anh, N. X. Trach and S. G. Sommer, J. Cleaner Prod., 2012, 27, 64-71.

12 X. Y. Jiang, S. G. Sommer and K. V. Christensen, Energy Policy, 2011, 39, 6073-6081.

13 K. Gondek, M. Mierzwa-Hersztek and M. Kopeć, J. Environ. Manage., 2018, 222, 132-134.

14 D. Lu, L. X. Wang, B. X. Yan, Y. Ou, J. N. Guan, Y. Bian and Y. B. Zhang, Waste Management, 2014, 34, 1529-1536.

15 J. Singh, R. Prasad and A. S. Kalamdhad, Res. J. Chem. Environ., 2013, 17, 26-34.

16 Y. W. Liu, Y. B. Zhang, X. Quan, Y. Li, Z. Q. Zhao, X. S. Meng and S. Chen, Chem. Eng. J., 2012, 192, 179-185.

17 Y. H. Feng, Y. B. Zhang, X. Quan and S. Chen, Water Res., 2014, 5, 242-250.

18 H. J. Li, J. L. Chang, P. F. Liu, L. Fu, D. W. Ding and Y. H. Lu, Environ. Microbiol., 2015, 17, 1533-1547.

19 J. Q. Xu, R. L. Yu, X. Y. Dong, G. R. Hu, X. S. Shang, Q. Wang and H. W. Li, J. Hazard. Mater., 2012, (217-218), 58-66.

20 J. Sheng, W. J. Lu and H. T. Wang, J. Environ. Sci., 2007, 28, 1367-1371.

21 X. M. Lu, P. Z. Lu, J. J. Chen, H. Zhang and J. Fu, Environ. Sci. Pollut. Res., 2015, 22, 14727-14737.

22 C. Huiliñir, S. Montalvo and L. Guerrero, Water Sci. Technol., 2015, 72, 230-237.

23 H. J. Li, J. L. Chang, P. F. Liu, L. Fu, D. W. Ding and Y. H. Lu, Environ. Microbiol., 2015, 17, 1533-1547. 
24 F. Suanon, Q. Sun, D. Mama, J. W. Li, B. Dimon and C. P. Yu, Water Res., 2016, 88, 897-903.

25 M. H. Zwietering, I. Jongenburger, F. M. Rombouts and 'R. K. Van, Appl. Environ. Microbiol., 1990, 56, 1875-1881.

26 Y. Mu, X. J. Zheng, H. Q. Yu and R. F. Zhu, Int. J. Hydrogen Energy, 2006, 31, 780-785.

27 Y. S. Liu, L. L. Ma, Y. Q. Li and L. T. Zheng, Chemosphere, 2007, 67, 1025-1032.

28 A. Tessier, P. G. Campbell and M. Bisson M, Anal. Chem., 1979, 51, 844-851.

29 Y. G. Liang, S. S. Yin, Y. B. Si, Z. Zheng, S. J. Yuan, E. Nie and X. Z. Luo, Chem. Eng. J., 2014, 237, 209-216.

30 APHA A WEF, Standard methods for the examination of water and wastewater, American Public Health Association, Washington, DC, 19th edn, 1995.

31 H. B. Zhou, H. B. Meng, L. X. Zhao, Y. J. Shen, Y. Q. Hou, H. S. Cheng and L. Q. Song, Bioresour. Technol., 2018, 258, 279-286.

32 S. Meunchang, S. Panichsakpatana and R. W. Weaver, Bioresour. Technol., 2005, 96, 437-442.

33 Q. Zhou, C. J. Yan and W. J. Luo, Mater. Des., 2016, 92, 701709.

34 L. D. Garfield, D. Dixon, P. Nowotny, F. E. Lotrich, B. G. Pollock, S. D. Kristjansson, P. M. Doré and E. J. Lenze, Biomass Bioenergy, 2014, 71, 299-310.

35 Y. Yang, J. L. Guo and Z. Q. Hu, Water Res., 2013, 47, 67906800.

36 F. Aulenta, S. Fazi, M. Majone and S. Rossetti, Process Biochem., 2014, 49, 2235-2240.

37 V. C. Cruz, S. Rossetti, S. Fazi, P. Paiano, M. Majone and F. Aulenta, Environ. Sci. Technol., 2014, 48, 7536-7543.

38 P. C. Gao, X. B. Tang, Y. N. Tong and Y. X. Chen, Waste Management, 2008, 28, 1630-1636.

39 C. Shi, X. D. Liao, Y. B. Wu and J. B. Liang, Anim. Feed Sci. Technol., 2011, 166, 457-463.

40 L. Ferreira, T. Souza, F. Fdz-Polanco and S. Pérez-Elvira, Bioresour. Technol., 2014, 152, 393-398.

41 C. Viggi, S. Rosserri, S. Fazi, P. Paiano, M. Majione and F. Aulenta, Environ. Sci. Technol., 2014, 48, 7536-7543.

42 E. Baek, J. Kim and C. Lee, Bioresour. Technol., 2016, 222, 344-354.
43 C. Yamada, S. Kato, Y. Ueno, M. Ishii and Y. Igarashi, J. Biosci. Bioeng., 2015, 119, 678-682.

44 G. Y. Zhen, X. Y. Lu, Y. Y. Li, Y. Liu and Y. C. Zhao, Chem. Eng. J., 2015, 263, 461-470.

45 X. Kong, Y. H. Wei, S. Xu, J. G. Liu, H. Li, Y. L. Liu and S. Y. Yu, Bioresour. Technol., 2016, 211, 65-71.

46 I. Siegert and C. Banks, Process Biochem., 2005, 40, 34123418.

47 Y. G. Orha and B. Demirel, Process Biochem., 2013, 48, 901911.

48 R. Rajagopal, D. I. Massé and G. Singh, Bioresour. Technol., 2013, 143, 632-641.

49 F. Zucconi, M. Forte, A. Monac and M. Beritodi, BioCycle, 1982, 22, 27-29.

50 Y. S. Wei, Y. B. Fan, M. J. Wang and J. S. Wang, Resour., Conserv. Recycl., 2000, 30, 277-300.

51 L. Appels, J. Baeyens, J. Degreve and R. Dewil, Prog. Energy Combust. Sci., 2008, 34, 755-781.

52 F. Li, Z. Li, P. Mao, Y. W. Li, Y. X. Li, M. B. McBride, J. T. Wu and P. Zhuang, Environ. Sci. Pollut. Res., 2018, 9, 1-10.

53 N. M. Zhu, Q. L. Li, X. J. Guo, H. Zhang and Y. Deng, Ecotoxicol. Environ. Saf., 2014, 102, 8-24.

54 P. Xu, G. M. Zeng, D. L. Huang, C. L. Feng, S. Hu, M. H. Zhao, C. Lai, Z. Wei, C. Huang, G. X. Xie and Z. F. Liu, Sci. Total Environ., 2012, 424, 1-10.

55 S. C. N. Tang and I. M. C. Lo, Water Res., 2013, 47, 2613-2632. 56 M. Luna-Delrisco, K. Qrupõld and H. C. Dubourguier, J. Hazard. Mater., 2011, 189, 603-608.

57 L. Dąbrowska and A. Rosińska, Chemosphere, 2012, 88, 168173.

58 H. M. Jin and Z. Z. Chang, Appl. Biochem. Biotechnol., 2011, 164, 268-282.

59 Y. G. Liang, X. J. Li, J. Zhang, L. G. Zhang and B. J. Cheng, Environ. Sci. Pollut. Res., 2017, 24, 12328-12337.

60 X. Xiong, Y. X. Li, J. Han, C. Y. Lin, C. Suo and Z. Q. Zhang, J. Agro-Environ. Sci., 2008, 27, 2137-2142.

61 E. Donner, C. G. Ryan, D. L. Howard, B. Zarcinas, K. G. Scheckel, S. P. McGrat, M. D. Jonge, D. Paterson, R. Naidu and E. Lombi, Environ. Pollut., 2012, 166, 57-64.

62 Z. T. Yao, X. S. Ji, P. K. Sarker, J. H. Tang, L. Q. Ge, M. S. Xia and Y. Q. Xi, Earth-Sci. Rev., 2015, 141, 105-121. 